ФЕНОМЕН «СКЛЯНОї СТЕЛІ»

У ЗАКЛАДАХ ВИЩОЇ ОСВІТИ УКРАЇНИ

\section{THE «GLASS CEILING» PHENOMENON IN HIGHER EDUCATION INSTITUTIONS IN UKRAINE}

УДК 378(477):316.346.2-055.2 DOI https://doi.org/10.32843/26635208.2020.14.7

\section{Медіна Т.В.}

к.соціол.н.,

доцент кафедри соціології, соціального забезпечення

та місцевого самоврядування

Чернівецький національний університет

імені Юрія Федьковича

Загоруйко л.о.

к.пед.н.,

доцент касредри іноземних мов

Уманський державний педагогічний

університет імені Павла Тичини
У статті наводяться результати емпіричного дослідження щодо можливостей доступу жінок до найвищих адміністративних посад в українських університетах. Використано метод глибинного інтерв'ю, проведеного з представницями найвищих адміністративних посад у закладах вищої освіти. З'ясовано, що якості, необхідні для кар'єрного успіху, є гендерно нейтральними. Це працелюбність, виконавська дисципліна, вміння спілкуватися, красномовство, любов до своєї роботи. Визначено труднощі, які заважають жінкам у процесі їхнього кар'єрного заростання: гендерні стереотипи, репродуктивна фрункція жінок, а також виконання сімейних ролей. Чоловіки не стикаються із цими перепонами, тому їм кар'єру зробити легше.

Проаналізовано вплив сімейного статусу на можливості посадового зростання. Він $\epsilon$ двозначним: виконання сімейних ролей ускладнює кар'єру; підтримка з боку чоловіків відіграла важливу роль у питаннях кар'єрного зростання респонденток. Зроблено спробу пояснити френомен «зникнення жіночої обдарованості». Серед причин зазначено завищені вимоги до себе, відсутність необхідного середовища, спечисрічне гендерне виховання, переобтяженість сімейними обов'язками. Сучасні молоді жінки змінюють життєву стратегію, відтерміновуючи створення сім'ї та надаючи перевагу кар'єрному зростанню в молодому віці.

3'ясовано, що більшість респонденток стикалася у своїй профресійній діяльності з існуванням гендерних стереотипів. Виявлено суперечність між такою оцінкою наявності гендерної дискримінації в їх оточенні та оцінкою наявності дискримінації в політичній, фрінансовій сфрерах та сімейному житті. Виявлено відсутність гендерних відмінностей в оплаті праці в системі вищої освіти України.

Ключові слова: гендер, заклади вищої освіти, гендерна дискримінація, «скляна стеля», френомен «зникнення жіночої обдарованості», глибинне інтерв'ю.

The article presents the results of an empirical study on women's access to higher administrative positions in Ukrainian universities. The method of in-depth interviews conducted with representatives of the administrative positions in higher education institutions was used. It was found that the qualities necessary for career success are gender-neutral. They are the following: a hard work, communication skills, eloquence, and love for your work. Gender stereotypes, women's reproductive function, as well as the performance of family roles hindered women in the process of their career growth. Men do not face the mentioned obstacles, so it is easier for them to make a career.

The influence of family status on career growth opportunities has been analyzed. It is suggestive: performing family roles complicated the career growth; support from men played an important role in the issue of career growth. The authors tried to explain the phenomenon of "disappearance of female giftedness". Excessive requirements for themselves, lack of the necessary environment, specific gender education, and overloaded family responsibilities were among the reasons. Today's young women are changing their life strategy, putting off starting a family and preferring career growth at a young age.

The research stated that the majority of respondents had faced the existence of gender stereotypes in their professional activities. There is a contradiction between this assessment of gender discrimination presence in their environment and the assessment of the presence of discrimination in political, financial and family life. There are no gender differences in remuneration in the higher education system of Ukraine.

Key words: gender, higher education institutions, gender discrimination, «glass ceiling», phenomenon of «disappearance of female giftedness», in-depth interview.
Постановка проблеми. Нерівність за ознакою статі певною мірою притаманна всім суспільствам незалежно від рівня соціально-економічного розвитку, державного ладу або політичного устрою країни. Різні соціальні ролі, які покладає суспільство на жінок та чоловіків, визначають нерівні можливості самореалізації цих гендерних груп в окремих сферах життя: у доступі до владних структур, здобутті освіти, становищі на ринку праці та можливостях отримання доходу, володінні власністю та прийнятті рішень на рівні домогосподарства тощо.
На освітньому рівні гендерний аспект проблеми наукових і педагогічних кадрів дедалі частіше виступає предметом спеціальних порівняльних досліджень як міжнародних організацій, так і окремих дослідників, адже доступ жінок до адміністративних посад у школах та закладах вищої освіти є одним із показників реальної рівності у сфері освіти і трудовій сфері взагалі.

Середні позиції України в Глобальному звіті щодо гендерного розриву-2020 (59-е місце зі 153 країн) стали можливими завдяки високому рівню освіти населення, а також рівним 
умовам для жінок і чоловіків в отриманні освіти [9, с. 13]. На жаль, за іншими критеріями економічною участю та можливостями $(0,737)$ і політичними повноваженнями $(0,171)$ - Україна посідає значно гірші позиції.

Структура сучасного українського суспільства залишається патріархальною: високооплачувана і престижна робота, як правило, дістається чоловікам. Статистика свідчить, що за однакову з чоловіком роботу жінка одержує менше не тільки в Україні, а й у більшості країн світу. Доступ до професійних занять і кар'єри, що неймовірно збільшився для жінок порівняно з початком XX ст., поки що має кількісний вимір і часто не призводить до необхідних якісних зсувів [1]. Идеться не стільки про завоювання статусних позицій в ієрархічних структурах управління виробництвом, скільки про істотну зміну самого його характеру. Водночас домашнім господарством займається, як правило, жінка, що означає подвійне навантаження. Хоча такий стан справ несправедливий, до нього звикли і не завжди хочуть його змінювати навіть самі жінки.

Усе вищезазначене стосується й системи вищої освіти, яка, за логікою, повинна бути найчутливішою до нововведень та найбільш прогресивною. Але навіть неуважний погляд на сайт будь-якого університету зможе зафіксувати тенденцію переважання чоловіків на керівних посадах у ЗВО.

Аналіз останніх досліджень і публікацій. Освіта як така, у тому числі й вища, є гендерованим соціальним інститутом, тобто гендерний складник присутній у процесах, практиках та ідеологіях, а головне - у розподілі влади, які визначають функціонування цієї сфери. Так, згідно з результатами дослідження, проведеного Організацією «Європейська платформа для науковиць» (2018р.), жінки обіймають у середньому лише 19\% академічних посад, попри те що вони становлять понад 50\% студентів ЄС і отримують 45\% докторських ступенів у країнах ЄС. У деяких країнах цей відсоток ще нижчий. Зокрема, це пов'язано з тим, що науковиці у різнихчастинахсвітузіштовхуються з несприйняттям їхньої професійності [6].

Дослідники оцінюють гендерну сегрегацію як прояв гендерної нерівності як на робочому місці, так і в освіті [3; 5]. Вони виявили кореляційний зв'язок між посадою і вибором напряму підготовки в університеті, а також із зацікавленістю деякими предметами ще в школі.

На думку деяких дослідників, жінки від самого початку свого кар'єрного зростання можуть не бажати отримувати висококваліфіковані робочі місця, оскільки стикаються зі стереотипізацією [10; 8; 7; 4].

Предметом деяких емпіричних досліджень були рівні можливості доступу жінок до посад у системі вищої освіти. Так, Т. Тіммерс із коле- гами виокремили три групи чинників, які впливають на низьке представництво жінок на адміністративних посадах у ЗВО, а саме: індивідуальні, культурні та структурні (інституційні) [11]. Автори цього дослідження припустили, що зазначені чинники впливають на політикущодо збільшення частки жінок на університетських посадах.

На жаль, в українській науці вивчення питання гендерної сегрегації в системі вищої освіти вивчено недостатньо. Припускаємо, що поєднання кількісних та якісних методів дасть змогу поглибити уявлення щодо причин і проявів цього явища.

Постановка завдання. Дослідження за допомогою якісного методу збору інформації (глибинних інтерв'ю) проводилося в квітні 2020 р. Вибіркову сукупність становили жінки, які обіймають адміністративні посади у ЗВО тих рівнів, що аналізувалися у дослідженні за допомогою кількісного методу: дві ректорки, дві проректорки та дві деканесси класичного, медичного, технічного та педагогічного університетів із різних регіонів України. Було проведено шість інтерв'ю, середня тривалість яких становила 35 хвилин.

Гайд глибинного інтерв'ю включав чотири тематичних блоки: якості успішної жінки та складники особистого успіху; роль сім'ї у професійному зростанні жінки; судження щодо причин гендерної сегрегації; наявність гендерної дискримінації та стереотипів; пропозиції щодо подолання гендерної дискримінації у ЗВО. В основу кодування покладений опис статусів, які взято до аналізу: перша буква - посада в університеті (Р-ректорка, Пр - проректорка, Д - жінка-декан); друга буква - напрям університету (К - класичний, Т - технічний, П - педагогічний, М - медичний); третя позначка - регіон місцезнаходження університету (3x - Західний, Сx - Східний, Пд - Південний, Пн - Північний); цифра - номер інтерв'ю(від 1 до 6, упорядкузборуінформації).

Інтерв'ю за згодою респонденток записувалося на диктофон. Жодна учасниця глибинного інтерв'ю не відмовилася відповідати на питання дослідниць. Опитування були проведені 3 дотриманням етичних дослідницьких стандартів: респонденткам забезпечено повну конфіденційність їхніх персональних даних. У подальшому викладі отриманих результатів наведена інформація з інтерв'ю із закодованими даними про респонденток. Кодування учасниць наведено в табл. 1.

У зв'язку з пандемією та дистанційним режимом роботи інтерв'ю проводилися в телефонному режимі, за згодою учасниць був зроблений аудіозапис інтерв'ю з подальшим кодуванням і транскрибуванням. Зміст транскриптів було проаналізовано відповідно до керівних принципів Коена, Маніона та Моррісона (2007р.) для аналізу якісних даних. 
Кодування учасниць

\begin{tabular}{|c|c|l|c|c|c|}
\hline $\begin{array}{c}\text { № } \\
\text { iнтерв'ю }\end{array}$ & \multicolumn{1}{|c|}{ Посада } & \multicolumn{1}{|c|}{$\begin{array}{c}\text { Науковий } \\
\text { ступінь }\end{array}$} & $\begin{array}{c}\text { Напрям } \\
\text { університету }\end{array}$ & \multicolumn{1}{|c|}{ Регіон } & Кодування \\
\hline 1 & Ректорка & Докторка педагогічних наук & педагогічний & Західний & Р-П-3х-1 \\
\hline 2 & Проректорка & Кандидатка педагогічних наук & педагогічний & Східний & Пр-П-Сх-2 \\
\hline 3 & Деканеса & $\begin{array}{l}\text { Докторка фізико-математич- } \\
\text { них наук }\end{array}$ & класичний & Західний & Д-К-3х-3 \\
\hline 4 & Проректорка & Докторка психологічних наук & медичний & Південний & Пр-М-Пд-4 \\
\hline 5 & Ректорка & Докторка медичних наук & медичний & Східний & Р-М-Сх-5 \\
\hline 6 & Деканесса & Докторка технічних наук & технічний & Північний & Д-Т-Пн-6 \\
\hline
\end{tabular}

Зауважимо, що авторками було проведено також вивчення сайтів 70 університетів, яке дало можливість отримати інформацію про кількісне представництво жінок на адміністративних посадах [2]. Для розкриття зазначеної в назві теми кількісний метод важливий із погляду визначення частки жінок на вищих посадах ЗВО та співставлення з матеріалами якісного дослідження.

Виклад основного матеріалу дослідження. Згідно з отриманими за допомогою статистичного методу даними, жінки серед ректорів становлять 10\% (найвищий рівень представництва жінок - у педагогічних університетах), проректорів-22,7\%, деканів-31,7\%. Як бачимо, незважаючи на загальну тенденцію до фемінізації вищої освіти (через низку причин, які можуть бути предметом спеціального вивчення), кількість жінок на вищих посадах ЗВО не відповідає іх представництву в складі колективів університетів. Отже, можемо прослідкувати ефект «скляної стелі».

Попри те, що статистичний аналіз представленості жінок на посаді проректора не включав урахування їхніх функціональних обов'язків, проте здебільшого їм довіряють виховну роботу та міжнародні зв'язки. Проректор із виховної роботи, за словами однієї з учасниць, має зневажливий статус «проректора з танців» (Пр-М-Пд-4), а посада проректора 3 міжнародних зв'язків передбачає вільне володіння іноземною мовою, тому її часто обіймають представниці факультетів іноземних мов, де переважну більшість становлять жінки.

Учасниці глибинних інтерв'ю сформулювали якості, необхідні для кар'єрного зростання. Серед них найважливішими є такі: лідерство, працелюбність, відповідальність, професіоналізм, відданість справі, щоб довіряли люди. Важливим моментом виявилась достатня самооцінка: «...має бути достатня самооцінка, не занижена. Вона мені завжди заважала, і коли я почала ії трохи відсовувати, то це допомогло» (Пр-П-Сх-2) . Також серед якостей згадувалася удача: «Потрібно, щоб зірки зійшлися. Попасти в цей самий час і в це саме місце» (Р-П-3x-1). Потрібно вміти «... розписати алгоритм досягнення мети.
Тоді з'являється довіра до конкретної людини, довіра до її висловлювань, а якщо $є$ довіра, то під час вибору на якусь посаду це важливо для обрання» (Пр-П-Сх-2). Отже, перераховані якості не є гендерно орієнтованими.

Однією з гіпотез дослідження була та, що якості, необхідні для кар'єрного зростання жінок, мають відрізнятися від якостей чоловіків. На думку більшості учасниць глибинних інтерв'ю, вони дійсно відрізняються. 3 одного боку, вони мають психологічні відмінності, пов'язані з нижчим рівнем тестостерона, психофізіологічними показниками. 3 іншого боку, жінки в процесі самореалізації використовують жіночі гендерні особливості, наприклад: «З боку жінки інколи це може бути і хитрість або, навпаки, чарівність. Під час уміння переконувати саме і включається у жінок ось ця чарівність, і вона може допомогти» (Пр-П-Сх-2).

Зауважимо, що учасниці дослідження, які належать до технічних спеціальностей, не бачать відмінностей в якостях, необхідних для кар'єрного зростання жінок і чоловіків.

Усі учасниці дослідження визнали, що чоловікам легше зробити кар'єру. Серед аргументів були названі існування споконвічних стереотипів; репродуктивна функція жінок, яка пригальмовує, а часто ускладнює можливість кар'єрного зростання; сімейні турботи, яких у чоловіків менше.

Одним із завдань дослідження було з'ясування якостей, які сприяли успіху в кар'єрі учасниць дослідження. Окрім працелюбності, яку назвали всі учасниці, важливою є виконавська дисципліна: «Коли мені давали завдання виконати якусь роботу, то ніколи не відкладала на потім і зразу все негайно і часто через силу робила» (Пр-П-Сх-2). Варто звернути увагу на таку якість, як уміння спілкуватися і вміння почути кожного, бачити всіх людей із позитивного боку, а не з негативного.

Респондентками був запропонований рецепт їхнього успіху: працелюбність, результативність, вихід із зони комфорту, красномовство, вміння виступати на публіці, любити свою роботу. Як бачимо, ці риси характеру не $€$ гендерно орієнтованими, тому неможливо вивести рецепт саме «жіночого» чи «чолові- 
чого» успіху в кар'єрі адміністративного персоналу ЗВО. Щодо цього так і сказала одна з учасниць: «Не має бути ніяких гендерно орієнтованих якостей» (Д-К-3x-3).

Однією з гіпотез була та, що сімейний статус науковиці впливає на можливості посадового зростання. Зокрема, заміжнім жінкам важче поєднувати належне виконання сімейних обов'язків із професійною кар'єрою.

Виявилося, що всі учасниці дослідження заміжні, підтримка чоловіків відіграла в їхній кар'єрі велику роль:

«Заміжні (більш успішні в кар'єрному зростанні). Вони відчувають якусь підтримку. Усі мої подруги, хто захистив докторську дисертацію, є заміжніми» (Д-Т-Пн-6); «як на мене, більш успішні заміжні жінки» (Пр-М-Пд-4); «людям хочеться бачити не лише успішних професійно, а й із гарними стосунками в сім'ї, якщо навіть дитина має гарні результати» (Д-К-Зх-3); «... можна робити кар'єру лише за підтримки чоловіка» (Р-П-3х-1).

Деякі учасниці зауважили, що сімейний статус жінки не впливає на можливості кар'єрного зростання: «Немає великої різниці між заміжня-незаміжня жінка. Це несуттєво позначається на службовому просуванні» (Пр-П-Сх-2).

Також зустрічалися суперечливі оцінки такого впливу:

«Якщо багато дітей і сімейних турбот, то ти не зможеш професійно рости й отримати посаду, бо просто не буде вистачати часу. Але, навпаки, якщо ти маєш сім'ю і відчуваєш підтримку в родині, чоловік радить і допомагає, то ця підтримка дуже важлива, і це додає сил» (Д-К-3x-3).

«Напевно, що сім'я вимагає часу, і це може трохи гальмувати цей процес. Коли треба буде написати статтю чи приготувати вечерю, то я буду готувати вечерю, але це часто забирає час мого сну. Думаю, що частково це може бути вплив. Але все залежить від людей» (Пр-П-Сх-2).

Отже, відібрані випадковим чином усі учасниці глибинних інтерв'ю були заміжніми, і більшість із них зазначила важливу роль підтримки подружнього партнера для їхнього кар'єрного зростання.

Для того щоб виявити причини явища «скляної стелі», учасниць глибинних інтерв'ю попросили пояснити причини феномену «зникнення жіночої обдарованості», коли кількість відмінників серед дівчат вища, ніж серед хлопців, а після отримання освіти (у тому числі й вищої) вони сходять з кар'єрної дистанції, залишаються в тіні, на другорядних ролях. На думку респонденток, саме комплекс відмінниці і робить жінку неуспішною: «...тому я стараюся нікого не підвести. Але це мінус» (Р-П-3х-1); «думаю, що комплекс відмінників заважає в житті. Вони перфекціоністки, й інколи, незважаючи на те що були відмінни- цями, у них занижена самооцінка. I це дійсно зупиняє в якийсь момент» (Пр-П-Сх-2). Отже, прагнення виконувати все на відмінно не дає можливості кар'єрного зростання через завищені вимоги до себе (а це, своєю чергою, має зворотний бік - занижену самооцінку). Имовірно, у програмах жіночого лідерства необхідно врахувати цю психологічну особливість здібних дівчат і спрямувати зусилля на формування адекватної самооцінки.

Також учасниці опитування зауважували, що для здібних дівчат немає підходящого середовища (Пр-М-Пд-4). І у цьому плані цікавим $€$ започаткування в Україні програми «Українська академія лідерства» , яка орієнтована на випускників шкіл віком від 16 до 20 років. Переможці конкурсного відбору отримують грант на 10-місячне навчання, проживання в кампусі, подорожі. Під час навчання та роботи студенти здобувають навички самопізнання, аналізу суспільних викликів, командної праці, комунікації, щоб краще зрозуміти себе, країну та світ, в якому ми живемо.

Частина учасниць пояснювала феномен «зникнення жіночої обдарованості» специфічним вихованням, а також переобтяженістю сімейними обов'язками: «Жінок виховують так, що у них єдине завдання - це успішно вийти заміж» (Д-К-ЗХ-3); «У нас ранні шлюби. I жінка відволікається на те, що $є$ важливим» (P-M-CX-5); «На початку жінкам заважають сімейні ролі» (Д-Т-Пн-6).

Разом із цим подібне виховання стосується далеко не всіх. Скоріше за все, респондентки екстраполюють власний досвід, оскільки вони зазначають, що «нове покоління вже по-іншому дивиться на світ. Тенденція у нас йде на зміну. Молоде покоління спершу хоче себе реалізувати професійно, а потім створити сім'ю» (Д-К-ЗХ-3); «У нашому українському суспільстві жінка амбіційна. Я дивлюся на наших студенток і розумію, що вони всі хочуть бути кимось» (Пр-М-Пд-4).

Отже, на думку учасниць дослідження, створення сім'ї в молодому віці $€$ перепоною для кар'єрного зростання молодих жінок, проте подібні стратегії вже не є масовими, частина дівчат орієнтована на досягнення кар'єрних успіхів, і лише після цього на створення сім'ї. Респондентки фіксують трансформацію життєвих стратегій частини їх студенток.

Однією 3 гіпотез дослідження була та, що жінки в системі вищої освіти України стикаються 3 явищем гендерної дискримінації. Згідно з відповідями більшої частини респонденток, в їхній професії це явище відсутнє: «Мені, навпаки, часто те, що я жінка, допомагало» (Д-К-Зх-3); «Деякі керівники віддають перевагу навіть жінкам, але чітко дивляться, щоб були вже діти не маленькі» (Д-Т-Пн-6). Лише одна із шести учасниць глибинних інтерв'ю зазначила, що проблема існує, до 
того ж це ректорка університету педагогічного спрямування, де більшість становлять жінки: «Я уже 11 чи 12 ректор і перша жінка. Чоловікам легше набагато» (Р-П-3x-1).

Більшість учасниць зазначає, що в їхньому оточенні 3 гендерною дискримінацією вони не стикаються, проте вона існує і найбільше проявляється в політичній, фінансовій сферах, а також у сімейному житті. Зауважимо, що глибинні інтерв'ю проводилися раніше, ніж аналіз сайтів ЗВО, томуминемоглинавестиаргументи щодо помітно нижчого представництва жінок на адміністративних посадах. Отже, учасниці дослідження не бачать наявного в університетах явища гендерної вертикальної сегрегації.

Для виявлення гендерної дискримінації респонденткам пропонувалося оцінити, чи $\epsilon$ відмінність в оплаті праці чоловіків і жінок у системі вищої освіти. Попри існування єдиної тарифної сітки, яка є гендерно нейтральною, можуть існувати латентні форми дискримінації у вигляді доступу до додаткових матеріальних виплат (наприклад, надбавок за рейтинги).

Усі учасниці дослідження стверджують, що вони мають однакові доходи з чоловіками.

Гендерні стереотипи є атрибутами повсякденного мислення, самоусвідомлення та взаємодії індивідів у соціальному просторі. Вони існують в усіх сферах нашого життя, у тому числі у професійній сфері. Серед питань гайду глибинного інтерв'ю було й питання наявності стереотипів в їхньому професійному середовищі (наприклад, успішна в науці жінка неуспішна в сімейному житті; жінка надто емоційна, щоб бути ефективним керівником). Більшість респонденток зазначає, що явище існує, але до них не застосовується: «Теоретично чула, але відношення такого до себе не спостерігала. По відношенню до інших людей, то такі ремарки допускаються. Сексизм, на жаль, присутній» (Р-М-СХ-5).

Висновки 3 проведеного дослідження. Згідно з результатами глибинних інтерв'ю, жінки-посадовиці заперечили існування дискримінації у вигляді нерівного доступу жінок до посад в їхній професійній діяльності, проте вона існує і найбільше проявляється політичній, фінансовій сферах, а також у сімейному житті. Це не збігається 3 результатами кількісного дослідження, яке дало змогу зафіксувати практичну відсутність жінок у складі ректорського корпусу (де вони становлять 10\%) і незначне представництво серед проректорів (22,7\%). Отже, жінки, успішні в кар'єрі, не помічають недостатнього представництва жінок в управлінні університетами.

Більшість учасниць дослідження стикалася у своїй професійній діяльності 3 існуванням гендерних стереотипів. I це є однією з причин того, що чоловікам легше зробити кар'єру. Жінкам також важче просуватися службовими сходинками через їхні гендерні особли- вості, пов'язані з виконанням репродуктивних і сімейних ролей.

Була спростована гіпотеза щодо існування кореляції між сімейним статусом жінок і можливостями їхньої професійної кар'єри. Статус заміжньої жінки спрацьовує суперечливо: з одного боку, ускладнює посадове просування внаслідок перевантаженості ролями, з іншого - підтримка подружнього партнера відіграє важливу роль. Створення сім'ї в молодому віці є перепоною для кар'єрного зростання молодих жінок, тому останнім часом відбувається трансформація їхніх життєвих стратегій (частина дівчат орієнтована на досягнення кар'єрних успіхів і лише після цього на створення сім'ї).

Отримані результати дослідження дають змогу розширити поле наукового пошуку, а саме з'ясувати проблеми чоловіків у науці (наприклад, низька оплата праці суперечить науковим інтересам, а необхідність утримувати сім'ю виштовхує їх з університетів), а також визначити чинники, що сприяють фемінізації інституту вищої освіти.

\section{ЛITEРАТУРА:}

1. Лабур О.В. Історіографічний абрис гендерних відносин в Україні : монограсрія. Київ : КНУБА, 2007.

2. Медіна Т., Загоруйко Л. Сегрегаційні процеси в університетському середовищі України: гендерний аспект. Матеріали IV Міжнародної наукової конореренції УАДО «Імплементація європейських стандартів в українські освітні дослідження», 26 червня 2020 р. Дрогобич, 2020. С. 187-191.

3. Bridges W. Rethinking Gender Segregation and Gender Inequality: Measures and Meanings. Demography. 2003. № 40(3). P. 543-568.

4. Ceci S.J., Williams W.M. Why Aren't More Women in Science? Top Researchers Debate the Evidence. 1st ed. Washington : American Psychological Association, 2007.

5. Charles M. Deciphering Sex Segregation: Vertical and Horizontal Inequalities in Ten National Labor Markets. Acta Sociologica. 2003. № 46(4). P. 267-287. URL : www.jstor.org/stable/4194993 (дата звернення: 25.06.2020).

6. European Platform of Women in Science (2020). Who we are. URL : https://epws.org/who-we-are/ (дата звернення: 25.06.2020).

7. Fine C., Jordan-Young R., Kaiser A., Rippon G. Plasticity, plasticity, plasticity ... the rigid problem of sex. Trends Cogn Sci. 2013;17(11):550-1.

8. Fine C. Delusions of Gender: The Real Science Behind Sex Differences. London : Icon Books, 2010.

9. Global Gender Gap Report 2020: Insight Report. Cologny/Geneva, Switzerland. URL : http://www3.weforum.org/docs/WEF_GGGR_2020.pdf (дата звернення: 25.06.2020).

10. Summers L.H. Remarks at NBER conference on Diversifying the Science \& Engineering Workforce. Harvard, 2016.

11. Tanya M. Timmers, Tineke M. Willemsen, Kea G. Tijdens. Gender diversity policies in universities: a multi-perspective framework of policy measures. High Educ (2010) 59:719-735. DOI : 10.1007/s10734-009-9276-z. 